\title{
The Sublimity of Serat Bayanullah Language as Islamic Da'wah Literacy (A Study of Stylistic)
}

\author{
Mila Indah Rahmawati1, Wakit Abdullah Rais ${ }^{2}$, and Prasetyo Adi Wisnu Wibowo ${ }^{3}$ \\ \{1Milaindahr_38@student.uns.ac.id, wakit.a.rais_1460@staff.uns.ac.id, \\ prasetyoadiwisnuwibowo@yahoo.co.id\} \\ ${ }^{1}$ Study Program of Descriptive Linguistic, Postgraduate, Sebelas Maret University, \\ ${ }^{2,3}$ Study Program of Javanese Literature, Faculty of Science and Culture, Sebelas Maret University
}

\begin{abstract}
Serat Bayanullah is one of the Javanese literary works that breathe Islam in the form of macapat songs created by Raden Panji Natarata. Utilization of the beauty of language in the process of creating this macapat song becomes a manifestation of the creativity and mastery of style. That is qualified from the author, to produce a beautiful song and become a valuable literary work. The beauty of the language evidenced by the productive use of assonance, alliteration, and purwakanthi lumaksita. This research uses a descriptive qualitative approach. Primary data source in the form of Serat Bayanullah Karya Raden Panji Natarata published by the "Djojo Bojo" foundation in 1975 in Surabaya. The secondary data sources refer to several studies and supporting books relating to the basis of thinking related to the propagation of propaganda delivered. Thus, in studying and interpreting the use of language used in Serat Bayanullah, this study uses stylistic theory. The results showed that the use of language in Serat Bayanullah was felt to be very appropriate to express ideas about the value of taste and the content of meaning as an Islamic propagation literacy.
\end{abstract}

Keywords: stylistic, serat Bayanullah, tembang, da'wah literacy

\section{Introduction}

As a literary work, literature is loaded with religious elements and has a close relationship with religious philosophy [1]. A song is a kind of mirror that is a representation of reality itself. Broadly, song encompasses the nature of life, death, human nature, and divinity. It is closely related to the spread of religion on Java, especially Islam. In its development, the spread of Islam in Java was covered by previous teachings, sometimes even involving the aspects of kejawen as its entry point. In this case, Islamic elements try to embedded in Javanese cultures such as shadow puppet shows, kicks of Javanese songs, stories of the past, to traditional ceremonies. Daily life in Javanese society that cannot separate from the religious framework can identify from literary works related to the process of Islamization of Java. Literary works that emerged from among writers noticed the dominant color of religion. Moreover, even tended to maintain the legalistic element in religion from the possibility of entering elements that were considered to contain misleading elements. In conveying Islamic teachings to the 
Javanese people, preachers tried to integrate the values of Javanese culture and Islam as a form of tolerance towards Javanese people who at that time had syncretistic beliefs [2].

This fact also has a considerable impact on the field of Javanese literature. In its development, Javanese literary works experience integration with Islamic values. So, that works that were born more or less have been colored by Islamic values as the essence of the author's philosophical process [3]. It has become the researcher's interest to study and interpret the Serat Bayanullah, which is one of Javanese literary works that breathe Islamic values. Assonance, alliteration, and purwakanthi lumaksita used to express the author, in any case. Therefore, researchers assume that is the uniqueness of Raden Panji Natarata as a form of author's individuality.According to Aminuddin, language is the raw material in the study of styles (stylistics) [4]. That means that the stylistic theory is suitable and appropriate to study linguistic expressions that are felt to represent something that the author wants to express [5]. Therefore, stylistic and semiotics are necessary to interpret the song meaning [6].

The object of research is limited to the dhandhanggula song on the opening pole of Serat Bayanullah only. The reason, great literary works have meaning and value [7]. In this case, the song dhandhanggula as a literacy of Islamic da'wah is also a significant literary work. Also, in delivering the message of da'wah that loads with the idea of Sufism, it generally begins with beautiful words and sentences, so that it is following the flexible character of dhandhanggula [8]. Furthermore, the dhandhanggula song as an opening in Serat Bayanullah has an intertextual relationship with the Qur'an, so that the song include in literary works of great value. The research aims to appreciate and uncover the meaning behind the beauty of the language of Serat Bayanullah by Raden Panji Natarata as part of the literary propaganda of Islam that he did.

\section{Research Method}

The research method used in this study uses three strategic stages, namely (1) the stage of providing data, (2) the stage of data analysis, and (3) the stage of presenting the results of data analysis [9]. The data supply stage uses library techniques, which uses written sources, which in this study, the written source is Serat Bayanullah. In this research, data analysis by describing linguistic phenomena in the form of assonance, alliteration, and purwakanthi lumaksita, as a form of stylistics by revealing the background and function of utilizing the linguistic aspects of the song. Furthermore, the meaning analysis is using the semiotic model reading method which consists of heuristic and hermeneutic readings to reveal the meaning of linguistic and meaning in Islamic propaganda literacy that is intended to be conveyed by Raden Panji Natarata [10].

\section{Results And Discussion}

Data analysis examines of assonance patterns (purwakanthi guru swara) or sound repetition, alliteration (purwakanthi guru sastra) or consonant repetition, and purwakanthi lumaksita which are systemize in the sequence of language sounds [11]. Patterns that are interrelated or intertwined give the feel of interrelationships between words in an array, between words in an array, or between lines. Thus the meaning to be conveyed becomes clear, forms poetic and rhythmic effects, and gives rise to beautiful orchestration [12]. 


\subsection{Utilization of Assonance (Purwakanthi Guru Swara)}

Utilization of assonance (purakanthi guru swara) in general to cause the effect of sound impairment, sound disorder, and the beauty of language [13].

\subsubsection{Assonance /o/ \\ tan gatra tan satmata (PDH1/G13/L10) \\ 'formless and invisible'}

Tan gatra tan satmata 'formless and invisible' data, has a sound suppression $/ \mathrm{o} /$ which is a form of assonance pattern. The assonance pattern $/ \mathrm{o} /$ in the word gatra 'shaped' is found in the first syllable and the last syllable (ultima), while in the word satmata 'seen' is found in the second syllable of the end (penultima) and the last syllable (ultima). Sound /o/ phonetically includes an open middle vowel, located at the back, and has a wide resonant space. Thus, the sound $/ \mathrm{J} /$ in the data above is a form of emphasis or affirmation.

In terms of meaning, the data above refers to the Formless and Invisible Invisible, which is Allah SWT. This is following the verse in the Qur'an, namely in the Surah Al-Ikhlas which explains the teachings of monotheism. Allah SWT is different from His creatures who have physical and visible forms. Allah, Almighty God, there is no one like Him..

\subsection{Assonance /al}

mangarepa harjaning tumitah (PDH1/G1/L1)

'hope for salvation in living the destiny of life'

The sound assonance pattern /a/ in the word mangarepa 'hope' found in the first syllable and the third syllable from the end. In the harjaning word 'salvation' is found in the first syllable and the second-last syllable (penultima), whereas in the word 'destiny' is found in the last syllable (ultima). Phonetically, the sound $/ \mathrm{a} /$ is an open low vowel and locate in the middle of the tongue [14]. The sound $/ \mathrm{a} /$ in the data above gives a great sense of motivation, enthusiasm, hope, and confidence. Mangarepa harjaning tumitah data 'hope for salvation in living the destiny of life' has a connection with the Qur'an in the Al-Baqarah verse 201 which contains a hope to God that He will give goodness in the world and goodness in the hereafter, and save from the torment of fire hell.

\subsection{Assonance /i/}

rina sawarga pinusthi-pusthi (PDH1/G7/L9)

'every day that is sought only paradise'

The sound /i/ asonance pattern in the word rina 'every day' is an open syllable and is found in the first syllable. In the pinusthi-pusthi kata that is sought ', the asonance /i/ pattern is located in the first syllable, the last syllable before the repetition of the pusthi word 'sought', and is in the last syllable (ultima) in the word pusthi 'sought'. The sound /i/ describes something light and small, because the vowel /i/ is characterized by a front, height, and a narrow resonant space.

The context of the song snippet in the data above is intended for humans who when doing worship is too excessive. As a servant, human nature is obedient to God by carrying out worship (hablumminaallah), as social beings the task of humans is to establish relationships and interactions with fellow humans (hablumminannas), and as a caliph on the face of the 
earth, humans need to pay attention to their relationship with the universe. This is following the words of the Prophet Muhammad SAW which means "Stay away from your attitude of ghuluw (excess) in religion because those before you have perished due to (excessive) in religion."

\subsection{Assonance/u/}

ngaku kukuh kuwat ing tyas (PDH1/G20/L8)

'claimed to have strong convictions'

The /u/ assonance pattern for the ngaku 'claimed' is an open syllable and is found in the last syllable (ultima). In the kukuh 'to have strong' and kuwat 'convictions' the asonance pattern is located in the first syllable and is an open syllable. The sound /u/ nuances are not easily swayed, steady, and strong. in this case, related to the strength or confidence of the heart. The context of the song excerpt above explains the heart's belief that God (God) is united in man. In the Al-Qaaf verse 16 verse, it is mentioned that Allah is closer to humans than human's jugular veins. The wrong understanding of the Al-Qaaf letter is the belief that the Essence of Allah is one with His creatures. Indeed the Essence of Allah remains in His Throne. The closeness in question is the angels of God who are always obedient to His commands, including in recording human deeds. In another opinion stated that the closeness in question is the closeness between a servant when he prayed and prostrated to his Lord, Allah SWT.

\subsection{Assonance $/ \hat{e} /$ \\ nèng angên-angên ênggone (PDH1/G2/L2) \\ 'in his mind's place'}

Data nèng angên-angên ênggone 'in his mind's place' shows the assonance pattern /ê/ in the word angên-angên 'his mind' is a closed syllable and contained in the last syllable (ultima). Sound /ê/ with consonant closed syllables /ng/ is identical to something unreachable or unlimited. As for the repeated ênggone 'place,' the assonance pattern /ê/ is located in the first syllable and is a closed consonant syllable $/ \mathrm{ng} /$, forming a clear and certain nuance.

The implied meaning of the above song snippet is that humans cannot imagine in their minds how the Essence of God will be. This is following the words of the Prophet, which means "Whatever comes to mind or the human mind about God, then God is not like that".

\subsection{Alliteration (Purwakanthi Guru Sastra)}

Abrams expressed his opinion that alliteration is the result of repeating sounds in the form of consonants, a combination of consonants and vowels, and repeating the same syllables in one or several lines of the song [15]. Therefore, alliteration makes the lyrics in a song sound more aesthetic.

\subsubsection{Alliteration $/ k /$}

kapti kerdyating Suksma (PDH1/G2/L10)

'hearts moved by Suksma' 
Sound $/ \mathrm{k} /$ is a dorsovelar which is an inhibitory consonant so that in pronouncing consonant $/ \mathrm{k} /$ there is the air that is obstructed in the articulation area. In the words kapti 'heart' and kerdyating 'moved by', and Suksma 'Suksma' the consonant /k/ is located in the first syllable. Thus, the sound pattern $/ \mathrm{k} /$ on the data of the capability of kerdyating Suksma 'hearts moved by Suksma' implies that everything done by humans starts from movements or conscience originating from Suksma. In this case, what is meant by Suksma is God. As a servant, humans should realize that whatever is desired happens by the permission of Allah, as stated in Surah Al-Muddatsir verse 56.

\subsection{Alliteration /p/}

\section{pinuja puji panjinge (PDH1/G16/L3)}

'adored and praised for his presence'

In the data pinuja puji panjinge 'adored and praised for his presence' the consonant loop $/ \mathrm{p} /$ is located in the first syllable. These consonants are bilabial, giving rise to a soft and smooth impression. Based on the context, the repetition $/ \mathrm{p} /$ in the song snippet explains the vigilance of the arrival of the Antichrist which is the greatest slander for mankind. Although the physical appearance has not been seen clearly, the Antichrist begins to appear in soft and subtle ways, so we may not realize it.

Some examples that we need to be aware of are the presence of the Antichrist gently and subtly such as the development of technology that is currently so fast compared with the rise of news and information that is not necessarily true. This is according to one of the characteristics of the Antichrist, which is good at lying and obscuring the truth. Therefore, even though it is not mentioned explicitly in the Qur'an, this dajjal slander needs to be watched out for.

\subsection{Utilization of Purwakanthi lumaksita}

Purwakanthi lumaksita is usually a repetition of syllables or words (free morphemes) in one array, inter-array, or between a song. The syllabic iteration distribution is at the beginning, in the middle, and at the end of the word. Furthermore, the repetition of words or parts of words has the potential for entire vocabulary

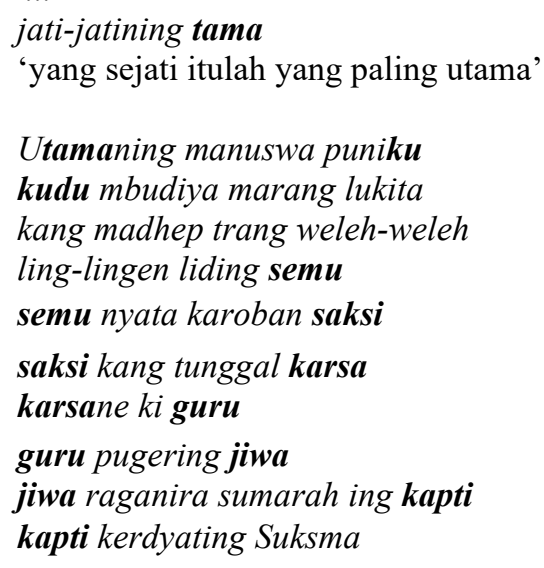


'the primary man'

'must strive for salvation'

'who have been firm and understand as clearly as possible'

'understand the implied secret'

'what is implied is what is real and what is real is less covered by the evidence'

'proof of one goal'

'at the wish of the God'

'God is a role model of soul'

'your soul and body that have surrendered to the heart'

'the heart that is moved by Suksma'

The purwakanthi lumaksita contained in the Serat Bayanullah dhandhanggula song shows a repetition between links in the data jati-jatining tama 'the truth is the most important' is repeated in the next verse utamaning mansuwa puniku 'the primary man'. The syllables $k u$ in the word of puniku 'that' are repeated in the next line in the word $\boldsymbol{k} \boldsymbol{u} d u$ 'must'. Furthermore, the repetition of words (free morpheme) between the lines is shown by the semu word 'implied', saksi 'evidence', karsa 'will', Guru 'teacher', jiwa 'soul', and kapti 'heart'. cause a sweet and poetic effect, so that following the character of the song dhandhanggula.

As for the core of the repetition in the data above, humans as beings who are endowed with thoughts and feelings must have a heart and soul sensitivity to everything that is implied. God as God has provided plenty of evidence of what He wants. Therefore, humans should be able to understand the will of God through what is in the universe and also study His words in the Qur'an.

\section{Conclusion}

The uniqueness of the beauty aspect of language in this dhandhanggula song of Serat Bayanullah is a valuable literary work. Utilization of assonance, alliteration, and purwakanthi lumaksita functions to create sound independence, emphasize meaning, and show cohesiveness between lines. Furthermore, by utilizing the beauty of these sound aspects, the author tries to convey the message of da'wah beautifully and does not seem to be patronizing, so that all people can enjoy the preaching.

\section{References}

[1] Mangunwijaya, Y.B., Sastra dan Religiousitas. Jakarta: Sinar Harapan, 1982.

[2] Kamal, M. A. M., "Interelasi Nilai Jawa dan Islam dalam Berbagai Aspek Kehidupan," Kalam, vol. 10, no. 1, pp. 19-42, 2016.

[3] O. Y. \& S. Pamungkas, "Gaya Ungkap Ranggawarsita dalam Puisi-puisinya (Suatu Tinjauan Stilistika, Sintaksis, dan Semantik)," in Jurnal Bahasa dan Sastra, 2016, vol. 3, no. 2, pp. 103 109.

[4] Aminuddin, M., Stilistika Pengantar Memahami Bahasa dalam Karya Sastra. Semarang: IKIP Semarang Press, 1995.

[5] Sudjiman, P., Bunga Rampai Stilistika. Jakarta: Pustaka Utama Grafiti, 1993.

[6] Al Ma'ruf, A. I., "Dimensi Sufistik dalam Stilistika Puisi 'Tuhan, Kita Begitu Dekat' Karya Abdulhadi W.M.," TSAQAFA, vol. 1, no. 1, pp. 101-118, 2012. 
[7] Niazi, N., "A Stylistic Analysis of D . H . Lawrence' s 'Sons and Lovers ," Int. J. Appl. Linguist. English Lit., vol. 2, no. 4, pp. 118-126, 2013.

[8] Padmoesoekotjo, S., Ngengrengan Kasusastran DjawaI \& II. Djokdja: Hien Hoo Sing, 1955.

[9] Sudaryanto, Metode dan Aneka Teknik Analisis Bahasa Pengantar Penelitian Wahana Kebudayaan secara Linguistis. Yogyakarta: SERI ILDEP, 1993.

[10] Riffaterre, M., Semiotic of Poetry. London: Routledge \& Kegan Paul, 1987.

[11] Bilal, A. H., "Stylistic Analysis of The Voice," vol. 4, no. 3, pp. 433-442, 2012.

[12] Wibowo M.A.K., Sumarlam, \& Satoto, S., "Pemanfaatan Bunyi Bahasa dalam Serat Wulang Reh

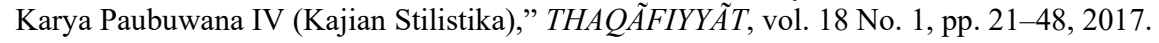

[13] Subroto, D.E., "Kajian Stilistika Teks Bahasa Pedalangan Wayang Purwa Gaya Surakarta," Bhs. dan Seni, vol. 41, no. 2, pp. 143-158, 1977.

[14] Verhaar, J.W.M., Asas-asas Linguistik Umum, 9th ed. Yogyakarta: Gadjah Mada Press, 2016.

[15] Abrams, M.H., A Glossary of Literary Terms. New York: Holt, Rinehart, and Wiston, 1981. 